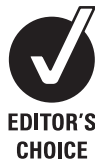

${ }^{1}$ Institute of Health and Society, William Leech Building, Newcastle University, Newcastle upon Tyne, UK; ${ }^{2}$ Department of Family Relations and Applied Nutrition, University of Guelph, Guelph, Ontario, Canada; ${ }^{3}$ Department of Community and Family Medicine, Duke University School of Medicine, Durham, North Carolina, USA

Correspondence to: Jean Adams, Institute of Health and Society, William Leech Building, Newcastle University, Newcastle upon Tyne NE2 4HH, UK; j.m.adams@ncl.ac.uk

Accepted 13 January 2009 Published Online First 28 May 2009

\title{
Food advertising during children's television in Canada and the UK
}

\author{
J Adams, ${ }^{1}$ K Hennessy-Priest, ${ }^{2}$ S Ingimarsdóttir, ${ }^{1}$ J Sheeshka, ${ }^{2}$ T Østbye, ${ }^{3}$ M White ${ }^{1}$
}

\section{ABSTRACT}

Background: Television advertisements for less healthy foods are thought to contribute to overweight and obesity in children. In the UK, new regulations on television food advertising to children came into effect in April 2007. These prohibit advertisements for "less healthy" foods during or around programmes "of particular appeal to" (OPAT) children. In Canada, self-regulated codes of practice on television food advertising to children were recently strengthened.

Objective: To document the nutritional content of food advertised and number of advertisements OPAT children broadcast in the UK and central Canada before the introduction of the new UK regulations.

Design: All food advertisements broadcast on four popular channels in Canada and the three terrestrial commercial channels in the UK during 1 week in 2006 were identified and linked to relevant nutritional data. Food advertisements OPAT children and for "less healthy" products were identified using the criteria in the UK regulations.

Results: 2315 food related advertisements broadcast in Canada and 1365 broadcast in the UK were included. 52$61 \%$ were for "less healthy" products; 5-11\% were OPAT children. Around $5 \%$ of food advertisements would have been prohibited under the new UK regulations. There were few differences in the nutritional content of food described in advertisements that were and were not OPAT children.

Conclusion: There was little evidence that food described in advertisements OPAT children were any less healthy than those that were not. Few food advertisements are likely to be prohibited by the new UK regulations.

The increasing prevalence of overweight and obesity in children in developed countries ${ }^{1}$ poses a significant threat to the long term health of those affected. ${ }^{2}$ A positive relationship between time spent watching television (TV) and body weight has been consistently documented among children. ${ }^{3-5}$ One possible reason for this is the large number of advertisements for less healthy foods on TV. ${ }^{6}$ Exposure to TV food advertising has an independent influence on children's food preferences, purchasing behaviour and purchasing requests. ${ }^{6}$ There is the additional potential that TV advertising of less healthy foods normalises such products.

Concerns over TV food advertising to children have led to increasing calls for regulation..$^{8-11}$ In the UK, Ofcom, the communications industry regulator, implemented new regulations in April 2007. ${ }^{12}$ Television advertisements on nonchildren's channels for foods identified as "less

\section{What is already known on this topic}

- New regulations on television food advertising to children were implemented in the UK in 2007

- Industry regulated codes of practice were strengthened in Canada.

- The nutritional content of foods advertised on TV to children in the UK and Canada, and the effect of new regulations, is not known.

\section{What this study adds}

- There were few differences in the type or nutritional content of food advertisements that were and were not "of particular appeal to" children.

- Foods advertisements "of particular appeal to" children were no less healthy than those that were not.

- Only around $5 \%$ of food advertisements would have been prohibited by the new UK regulations.

healthy"13 were prohibited during or around programmes "of particular appeal to" (OPAT) 4-9 year olds. The prohibition was extended to programmes OPAT 4-15 year olds in January 2008 with a more phased introduction on children's channels. Programmes OPAT children are defined as those where the proportion of individuals watching who are children is at least $20 \%$ more than the proportion of children in the population. In Canada, less specific self-regulated advertising codes of practice on TV food advertising to children were recently strengthened. ${ }^{14}$ Although there are likely to be international variations in TV food advertising, recent data suggest that TV food advertising in the UK and Canada is remarkably similar. ${ }^{15}$

Numerous content analyses have documented the types of food advertised on TV. ${ }^{6}{ }^{16-22}$ However, few authors have described the detailed nutritional content of the foods advertised. . $^{15} 162324$ Most previous analyses of food advertising to children have also focused specifically on children's programmes and channels, wrongly assuming that children's viewing is restricted to these times. ${ }^{25}$ Some notable exceptions that have studied advertising during the programmes that children watch most have been published in the last few years ${ }^{23}$ but no recent data are available from the UK or Canada. 
Thus, there are currently few detailed data available on the exact nutritional content of the foods that are being advertised on TV to children living in the UK or Canada. Furthermore, there are no published data on the number of advertisements, or on the nutritional content of the foods advertised, that will be subject to the new Ofcom regulations in the UK.

In order to provide baseline data from before the introduction of the UK Ofcom regulations and the Canadian codes of practice, we compared the type, nutritional content and proportion of food advertisements for "less healthy" products amongst all TV food advertisements with those OPAT children in the UK and central Canada.

\section{METHODS}

\section{Data sources}

Information on all advertisements broadcast on four popular free-to-view channels in Ontario and Quebec, Canada (CBC (Toronto), CTV (Toronto), A-channel and SRC (Montreal)) and all commercial terrestrial channels in the UK (ITV, Channel 4 and Channel 5) during the week beginning 30 October 2006 was obtained from audience research bureaux. These data included what products were advertised and an indicator of the number of viewers of each advertisement both overall and in age-specific groups (termed television ratings (TVR) in the UK and gross rating points (GRP) in Canada). The data covered $24 \mathrm{~h}$ and were not limited to any particular time of day.

\section{Identifying advertisements OPAT children}

TVR and GRP indicate the proportion of all individuals, or specific demographic groups, that watched any given advertisement. For the UK data, TVR were calculated based on viewing and population figures from across the UK. For the Canadian data, GRP were calculated based on figures from Toronto, Ontario for the English language channels (CBC (Toronto), CTV (Toronto) and A-channel) and from Montreal, Quebec for the French language channel (SRC (Montreal)). For each advertisement, TVR/GRP and population count data ${ }^{26}{ }^{27}$ were used to determine what proportion of individuals who were watching each advertisement were younger children and what proportion all children. Due to variations in the age groups for which TVR/GRP data are available, younger children were defined as aged 4-9 years in the UK and 2-11 years in Canada, and all children as aged 4-15 years in the UK and 2-17 years in Canada. As defined in the Ofcom regulations, those advertisements where the proportion of individuals watching who were children was at least $20 \%$ more than the proportion of children in the reference population, were identified as OPAT children.

\section{Categorical analysis of food related advertisements}

All food related advertisements (including those for both food and beverages, food stores and restaurants, but excluding those for vitamins and other supplements) were identified and categorised using a previously developed schema (table 1). ${ }^{16}$ The proportion of food related advertisements that fell into each category that were and were not OPAT younger and all children were compared using Fisher's exact test.

\section{Nutritional analysis of food advertisements and estimation of the "TV diet"}

For food advertisements (ie, excluding advertisements for food stores and restaurants), information on energy, protein, carbohydrate, sugar, fat, alcohol, fibre and sodium content and suggested portion size was obtained from packaging and manufacturers' websites as far as possible, supplemented with standard food table data in the $\mathrm{UK}^{28}$ where necessary. For advertisements for brand ranges rather than specific products, a single "default" product was identified based on the authors' consensus judgment of the most popular products within brand ranges, and the nutritional content for that product used in analyses.

We summarised the nutritional content of foods advertised using the concept of the "TV diet". ${ }^{16}$ To determine the composition of the TV diet, each advertisement was assumed to contribute one recommended sized portion of the product advertised. The total percentage of energy from each macronutrient, as well as fibre and sodium density (in grams per megajoule) for all foods advertised was then calculated. The composition of the TV diet was calculated for all food advertisements and for those OPAT younger and all children separately, and the results in both the UK and Canadian data sets compared.

Finally, the UK Food Standards Agency's nutrient profiling model ${ }^{13}$ was used to identify whether or not advertised foods were "less healthy". Differences in the proportion of food advertisements that were "less healthy", between those advertisements that were and were not OPAT younger and all children were assessed using Fisher's exact test.

\section{RESULTS}

Overall, 2315 food related advertisements broadcast in Canada and 1365 broadcast in the UK were included. In the Canadian sample, 105 (4.5\%) food-related advertisements were OPAT younger children and 152 (6.6\%) OPAT all children. Comparable figures from the UK were $139(10.2 \%)$ and 144 (10.5\%). The proportion of food advertisements that were OPAT younger and all children was significantly higher in the UK compared to Canada (Fisher's exact test $\mathrm{p}<0.001$ in both cases).

The distributions of food related advertisements across the food categories are shown in table 1 along with the results of Fisher's exact tests comparing the frequency of each category in those advertisements that were and were not OPAT children. Few statistically significant differences were seen. In Canada, advertisements for sauces, stocks and condiments were more common amongst advertisements OPAT younger children, and those for sweets and candy and food stores were less common amongst advertisements OPAT all children. In the UK, advertisements for grain products were more common and those for food stores less common amongst advertisements OPAT both younger and all children. Advertisements for milk and milk products were also more common amongst advertisements OPAT younger children in the UK.

The nutritional content of food advertisements (the TV diet) is summarised in table 2. In both Canada and the UK there was a consistent trend for food advertisements OPAT both younger and all children to have a markedly higher fibre density than all food advertisements. In Canada food advertisements OPAT younger and all children had a noticeably higher alcohol content than all advertisements. The reverse trend was seen in the UK. Food advertisements OPAT all children had a somewhat lower sugar content than all food advertisements in Canada.

Table 3 shows the proportions of food advertisements that were for "less healthy" foods. Advertisements for "less healthy" foods accounted for more than half of all food advertisements in all cases but made up a higher proportion of food advertisements in Canada than in the UK (Fisher's exact test $\mathrm{p}<0.001)$. The proportion of food advertisements that were for "less healthy" foods did not differ significantly 
Table 1 Food and food related advertisements in Canada and UK by food category

\begin{tabular}{|c|c|c|c|c|c|c|}
\hline \multirow[b]{2}{*}{ Food category } & \multicolumn{3}{|c|}{ Canada, n (\%) } & \multicolumn{3}{|l|}{ UK, n (\%) } \\
\hline & $\begin{array}{l}\text { All food } \\
\text { related ads }\end{array}$ & $\begin{array}{l}\text { Food related } \\
\text { ads OPAT } \\
2-11 \text { year } \\
\text { olds }\end{array}$ & $\begin{array}{l}\text { Food related } \\
\text { ads OPAT } \\
2-17 \text { year } \\
\text { olds }\end{array}$ & $\begin{array}{l}\text { All food } \\
\text { related ads }\end{array}$ & $\begin{array}{l}\text { Food related } \\
\text { ads OPAT } \\
4-9 \text { year } \\
\text { olds }\end{array}$ & $\begin{array}{l}\text { Food related } \\
\text { ads OPAT } \\
4-15 \text { year } \\
\text { olds }\end{array}$ \\
\hline Beverages & $241(10.4)$ & $11(10.5)$ & $21(13.8)$ & $215(15.8)$ & $17(12.2)$ & $19(13.2)$ \\
\hline Fisher's exact test $\mathrm{p}$ value & & $1.00 *$ & $0.17 \dagger$ & & $0.26^{*}$ & $0.47 \dagger$ \\
\hline Milk and milk products & $247(10.7)$ & $8(7.6)$ & $14(9.2)$ & $73(5.4)$ & $14(10.1)$ & $12(8.3)$ \\
\hline Fisher's exact test $p$ value & & $0.33^{*}$ & $1.00 \dagger$ & & $0.57^{*}$ & $0.57 \dagger$ \\
\hline Salty snacks & $7(0.3)$ & 0 & 0 & 0 & 0 & 0 \\
\hline Fisher's exact test $p$ value & & $1.00^{*}$ & $1.00 \dagger$ & & $-*$ & $-\dagger$ \\
\hline Grain products & $249(10.8)$ & $12(11.4)$ & $20(13.2)$ & $182(13.3)$ & $30(21.6)$ & $32(22.2)$ \\
\hline Fisher's exact test $p$ value & & $0.75^{*}$ & $0.34 \dagger$ & & $0.005^{*}$ & $0.002 \uparrow$ \\
\hline Meat and alternatives & $24(1.0)$ & $1(1.0)$ & $2(1.3)$ & $15(1.1)$ & $1(0.7)$ & $1(0.7)$ \\
\hline Fisher's exact test $p$ value & & $0.49 *$ & $0.02 \dagger$ & & $0.22^{*}$ & $0.86 \dagger$ \\
\hline Chewing gum & $11(0.5)$ & $2(1.9)$ & $1(0.7)$ & 0 & 0 & 0 \\
\hline Fisher's exact test $p$ value & & $0.09 *$ & $0.53 \dagger$ & & $-*$ & $-\dagger$ \\
\hline Sauces, stocks and condiments & $43(1.9)$ & $7(6.7)$ & $6(3.9)$ & $99(7.3)$ & $12(8.6)$ & $12(8.3)$ \\
\hline Fisher's exact test $p$ value & & $0.003^{*}$ & $0.06 \dagger$ & & $0.49^{*}$ & $0.61 \dagger$ \\
\hline Meals & $818(35.3)$ & $35(33.3)$ & $59(38.8)$ & $219(16.0)$ & $29(20.9)$ & $29(20.1)$ \\
\hline Fisher's exact test $p$ value & & $0.75^{*}$ & $0.38 \dagger$ & & $0.11^{*}$ & $0.19 \dagger$ \\
\hline Restaurants & $329(14.2)$ & $19(18.1)$ & $20(13.2)$ & 0 & 0 & 0 \\
\hline Fisher's exact test $p$ value & & $0.25^{*}$ & $0.81 \dagger$ & & $-{ }^{*}$ & $-\dagger$ \\
\hline Food stores & $109(4.7)$ & $1(1.0)$ & $2(1.3)$ & $370(27.1)$ & $23(16.5)$ & $23(16.0)$ \\
\hline Fisher's exact test $\mathrm{p}$ value & & $0.06^{*}$ & $0.04 \uparrow$ & & $0.002^{*}$ & $0.001 \uparrow$ \\
\hline All food related adverts & $2315(100)$ & $105(100)$ & $152(100)$ & $1365(100)$ & $139(100)$ & $144(100)$ \\
\hline
\end{tabular}

OPAT, "of particular appeal to".

*Comparing advertisements "of particular appeal to" younger children (2-11 or 4-9 year olds) with advertisements not "of particular appeal to" them using Fisher's exact test. †Comparing advertisements "of particular appeal to" all children (2-17 or 4-15 year olds) with advertisements not "of particular appeal to" them using Fisher's exact test.

between advertisements that were and were not OPAT younger or all children in either country.

\section{DISCUSSION}

This is the first detailed nutritional analysis of TV food advertising to children in either the UK or Canada that identified children's TV using viewing figures. Furthermore, this is the first published analysis of TV food advertising based on the new UK Ofcom regulations on TV food advertising to children. Five months before the implementation of these regulations, only $10-11 \%$ of food advertisements in the UK were OPAT children and would be subject to the regulations. In the Canadian data, $5-7 \%$ of food advertisements were OPAT children. There were few differences in either country between the types, or nutritional content, of foods that were promoted during advertisements that were and were not OPAT children. In all cases, more than half of food advertisements were for "less healthy" products. There was no evidence that the proportion of food advertisements that were for "less healthy" products differed between food advertisements that were and were not OPAT children in either country. Overall, 5-6\% of food advertisements in the UK sample would have been prohibited under the new regulations.

We used industry data on what advertisements were broadcast, who saw them and the nutritional content of foods advertised. Manufacturers' data on nutrient composition represent the most product-specific information available.
Given the dependence of the advertising industry on audience research bureaux viewing figures, they are also likely to be accurate.

The UK Ofcom regulations on TV food advertising to children refer to advertisements during or around programmes OPAT children. In contrast, we have focused on advertisements OPAT children. By focusing on advertisements shown during and around programmes OPAT children, the Ofcom regulations assume that audiences for programmes are very similar to those for the advertisements shown during and around them.

Early November was chosen as a typical period as being not too close to either season premieres or the holiday season. However, seasonal variations in food advertising may exist. Similarly, variations may exist in food advertising across parts of Canada and channels not studied here.

Our use of "default" products to represent the nutrient content of brand ranges advertised may have introduced some error. Although a very similar pattern of results to those reported here was found when using the mean nutrient content of all products in the brand ranges advertised (data not shown), the assumption that advertisements for brand ranges are comparable to advertisements for single products may be wrong.

As previously, we used standard portion sizes to determine the weight or volume of advertised products that contributed to the overall TV diet. ${ }^{23}{ }^{24}$ While standard portion sizes may substantially underestimate the true weight of products that individuals consume, they appear to do so to a consistent 
Table 2 Nutritional content of foods advertised in Canada and the UK

\begin{tabular}{|c|c|c|c|c|c|c|}
\hline \multirow[b]{2}{*}{ Nutrient } & \multicolumn{3}{|l|}{ Canada } & \multicolumn{3}{|l|}{ UK } \\
\hline & $\begin{array}{l}\text { All food ads } \\
(\mathrm{n}=1877)\end{array}$ & $\begin{array}{l}\text { Food ads OPAT } \\
2-11 \text { year olds } \\
(n=85)\end{array}$ & $\begin{array}{l}\text { Food ads OPAT } \\
2-17 \text { year olds } \\
(\mathrm{n}=130)\end{array}$ & $\begin{array}{l}\text { All food ads } \\
\text { ( }=995)\end{array}$ & $\begin{array}{l}\text { Food ads OPAT } \\
4-9 \text { year olds } \\
\text { ( } n=116 \text { ) }\end{array}$ & $\begin{array}{l}\text { Food ads OPAT } \\
4-15 \text { year olds } \\
\text { ( } n=121)\end{array}$ \\
\hline Carbohydrate (\% energy) & 45.1 & 45.8 & 45.6 & 47.0 & 48.8 & 49.0 \\
\hline Sugar (\% energy) & 16.2 & 16.3 & 15.4 & 16.0 & 16.0 & 16.4 \\
\hline Fibre (g/MJ) & 1.6 & 1.6 & 1.7 & 1.3 & 1.6 & 1.6 \\
\hline Sodium (g/MJ) & 0.5 & 0.5 & 0.5 & 0.4 & 0.4 & 0.4 \\
\hline
\end{tabular}

OPAT, "of particular appeal to".

degree. ${ }^{29}$ Our approach to quantifying the TV diet is, therefore, likely to represent a good estimation of the nutritional composition of a diet comprised of one real-life portion of every food advertised. However, the concept of the TV diet is intended more as a method of summarising advertised products than an indication of what television viewers actually eat. Advertisements are likely to vary in their ability to encourage consumption amongst viewers. As these analyses are descriptive only, they provide no information on the effect of advertisements on actual behaviour (although the advertisements' raison d'être is, of course, to influence behaviour).

Finally, due to variations in data availability, the age ranges used to define younger and all children varied between the UK and Canada and comparisons between the UK and Canadian data should be interpreted cautiously.

Between $5 \%$ and $11 \%$ of food advertisements met the definition of OPAT children. We assume these represent the food advertisements that, in the UK, are now subject to the Ofcom regulations on TV food advertising to children. In the UK sample, $5-6 \%$ of food advertisements (52-61\% of $10-11 \%$ ) would have been prohibited by the new regulations. Given the apparent political commitment to these regulations, ${ }^{10}{ }^{30}$ it is surprising that such a small proportion of food advertisements will be affected.

Our results are likely to be heavily reliant on the definition of what makes an advertisement OPAT children that we used (ie, when the proportion of individuals watching who were children was at least $20 \%$ more than the proportion of children in the reference population). This is the definition set out in the Ofcom regulations and is, therefore, highly policy relevant. However, other cut-offs or definitions may have resulted in different patterns of results.

It is possible that when our data were collected (5 months before the introduction of the Ofcom regulations) food manufacturers advertising in the UK were already changing their advertising strategies in anticipation of the regulations. However, the proportion of food advertisements that were
OPAT children was even lower in Canada than in the UK, suggesting that the low proportion of food advertisements that are OPAT children is not UK specific. In addition, more than half of food advertisements OPAT children were for "less healthy" products in both countries and there was no evidence that the proportion of "less healthy" products varied between advertisements that were and were not OPAT children in either country. Any changes in TV food advertising to children in the UK in advance of the introduction in the Ofcom regulations were not reflected in differences between the UK and Canada at this time. Further work will be required to determine how the food advertising landscape in the UK changes following full introduction of the Ofcom regulations.

Few differences were seen between advertisements that were and were not OPAT children in either the type or nutrient content of foods, or the proportion of foods that were "less healthy", in either country. This challenges a common perception that food advertisements broadcast during children's TV are particularly unhealthy compared to advertisements broadcast at other times. In fact, the one consistent difference between advertisements that were and were not OPAT children was a higher fibre density in foods described in advertisements OPAT children.

Two papers from the USA describe the nutritional content of foods advertised during programmes popular with children. ${ }^{23} 24$ Although methods vary, two clear trends are apparent: the percentage of energy derived from sugar is substantially lower in our samples than previously (around 16\% here compared to $34 \%{ }^{24}$ and $46-49 \%{ }^{23}$ previously) and the percentage of energy derived from fat is much higher in our samples than previously (around $35 \%{ }^{24}$ here compared to $27 \%$ and $18-19 \%{ }^{23}$ previously). This confirms that there are substantial international variations in the nutritional content of foods advertised on TV.

\section{CONCLUSIONS}

This is the first published study exploring TV food advertising to children in the context of the Ofcom regulations implemen-

Table 3 Proportion of food advertisements that met the FSA definition of "less healthy" in Canada and the UK

\begin{tabular}{|c|c|c|c|c|c|c|}
\hline \multirow[b]{2}{*}{ Healthfulness } & \multicolumn{3}{|c|}{ Canada, n (\%) } & \multicolumn{3}{|l|}{ UK, n (\%) } \\
\hline & $\begin{array}{l}\text { All food } \\
\text { related ads }\end{array}$ & $\begin{array}{l}\text { Food related } \\
\text { ads OPAT } \\
\text { 2-11 year olds }\end{array}$ & $\begin{array}{l}\text { Food related } \\
\text { ads OPAT } \\
2-17 \text { year olds }\end{array}$ & $\begin{array}{l}\text { All food } \\
\text { related ads }\end{array}$ & $\begin{array}{l}\text { Food related } \\
\text { ads OPAT } \\
\text { 4-9 year olds }\end{array}$ & $\begin{array}{l}\text { Food related } \\
\text { ads OPAT } \\
4-15 \text { year olds }\end{array}$ \\
\hline Less healthy & $1234(65.7)$ & $51(60.0)$ & $78(60.0)$ & $542(54.5)$ & $60(51.7)$ & $74(61.2)$ \\
\hline Fisher's exact test $p$ value & & $0.29 *$ & $0.15 \dagger$ & & $0.55^{*}$ & $0.12 \dagger$ \\
\hline
\end{tabular}

FSA, UK Food Standards Agency; OPAT, "of particular appeal to".

*Comparing advertisements "of particular appeal to" younger children (2-11 or 4-9 year olds) with advertisements not "of particular appeal to" them using Fisher's exact test. †Comparing advertisements "of particular appeal to" all children (2-17 or 4-15 year olds) with advertisements not "of particular appeal to" them using Fisher's exact test. 
ted in the UK in April 2007. Our data, collected before the implementation of the new regulations, provide a useful baseline against which future data can be compared. We found little evidence of substantial differences in the type, nutritional content or prevalence of "less healthy" foods between those advertisements that were and were not OPAT children in either the UK or Canada. Five months before the introduction of the Ofcom regulations only around $5-6 \%$ of food advertisement on the three main UK commercial channels would have been prohibited by the regulations.

Funding: JA is supported by a UK MRC Special Training Fellowship in Health Services and Health of the Public Research.

Competing interests: None.

\section{REFERENCES}

1. Speiser PW, Rudolf $\mathrm{MC}$, Anhalt $\mathrm{H}$, et al. Consensus statement: childhood obesity. J Clin Endocrinol Metab 2005:90:1871-87.

2. Reilly JJ, Methven E, McDowell ZC, et al. Health consequences of obesity. Arch Dis Child 2003:88:748-52.

3. Robinson TN. Television viewing and childhood obesity. Pediatr Clin North Am 2001;48:1017-25.

4. Caroli M, Argentieri L, Cardone M, et al. Role of television in childhood obesity prevention. Int J Obes 2004;28:S104-8.

5. Coon KA, Tucker KL. Television and children's consumption patterns: a review of the literature. Minerva Pediatr 2002;54:423-36.

6. Hastings G, Stead M, McDermott L, et al. Review of research on the effects of food promotion to children, final report for the Food Standards Agency. Glasgow: Centre for Social Marketing, 2003.

7. Anon. The elephant in the room: evolution, behaviouralism, and counteradvertising in the coming war against obesity. Harv Law Rev 2003;116:1161-84.

8. Nestle M. Food marketing and childhood obesity - matter of policy. N Engl J Med 2006;354:2527-9.

9. Halford JCG. Serving up trouble? Advertising food to children. Psychologist 2005;5:284-7.

10. Department of Health. Choosing health: making healthy choices easier. London: HMSO, 2004.

11. Public Health Association of Australia Inc. Television food advertising during children's viewing times - position statement. Deakin, ACT, Australia: Public Health Association of Australia Inc., 2006.

12. Ofcom. Television advertising of food and drink products to children - final statement. London: Ofcom, 2007

13. Rayner M, Scarborough P, Boxer A, et al. Nutrient profiles: development of final model. Final report for the Food Standards Agency. Oxford: British Heart Foundation
Health Promotion Research Group, Department of Public Health, University of Oxford, 2005.

14. Canadian Children's Food and Beverage Advertising Initiative. Self-regulation of children's advertising in Canada. See http://www.adstandards.com/en/ childrensinitiative/selfRegulation.html (accessed 17 April 2009).

15. Adams J, Hennessy-Priest J, Ingimarsdóttir $\mathbf{S}$, et al. Changes in food advertisements during 'prime-time' television from 1991 to 2006: a UK-Canada comparison. Br J Nutr 2009 Feb 25:1-10. [Epub ahead of print]

16. Østbye T, Pomerleau J, White $\mathrm{M}$, et al. Food and nutrition in Canadian "prime time" television commercials. Can J Public Health 1993;84:370-4.

17. Chapman K Nicholas $P$, Supramaniam R. How much food advertising is there on Australian television? Health Promot Int 2006;21:172-80.

18. Connor SM. Food-related advertising on preschool television: building brand recognition in young viewers. Pediatrics 2006;118:1478-85.

19. Lewis MK, Hill AJ. Food advertising on British children's television: a content analysis and experimental study with nine-year olds. Int J Obes Relat Metab Disord 1998;22:206-14.

20. Rodd HD, Patel V. Content analysis of children's television advertising in relation to dental health. Br Dent J 2005;199:710-12.

21. Chestnutt IG, Ashraf FJ. Television advertising of foodstuffs potentially detrimental to oral health - a content analysis and comparison of children's and primetime broadcasts. Community Dent Health 2002;19:86-9.

22. Dibb S, Gordon S. TV dinners: what's being served up by the advertisers? London: Sustain: the alliance for better food and farming, 2001.

23. Powell LM, Szczypka G, Chaloupka FJ, et al. Nutritional content of television food advertisements seen by children and adolescents in the United States. Pediatrics 2007; 120:576-83.

24. Harrison K, Marske AL. Nutritional content of foods advertised during the television programs children watch most. Am J Public Health 2005;95:1568-74.

25. Ofcom. Childhood obesity - food advertising in context: children's food choices, parents' understanding and influence, and the role of food promotion. London: Ofcom 2004.

26. nomis. Official labour market statistics. See http://www.nomisweb.co.uk laccessed 17 April 2009).

27. Statistics Canada. Table 051-0001 - Estimates of population, by age group and sex for July 1, Canada, provinces and territories, annual. CANSIM (database). Available at http://cansim2.statcan.ca/cgi-win/cnsmcgi.pgm? \&Lang =E\&Arrayld = 510001\&Array Pick $=1$ \&Detail $=1$ \&ResultTemplate $=\mathrm{CII} / \mathrm{Cl} \quad$ \&RootDir $=\mathrm{CII}$ (accessed 17 April 2009).

28. Food Standards Agency. McCance and Widdowson's the composition of foods. 6th edn. Cambridge: Royal Society of Chemistry, 2002.

29. Welten DC, Carpenter RA, McPherson RS, et al. Comparison of a dietary record using reported portion size versus standard portion size for assessing nutrient intake. Public Health Nutr 2000;3:151-8.

30. Butland B, Jebb S, Kopelman P, et al. Foresight tackling obesities: future choices project report. London: Government Office for Science, 2007. 